\title{
ADMRALTY JURISDICTION: THE OUTLOOK FOR THE DOCTRINE OF EXECUTIVE JET
}

\author{
RANDALL BRIWELL* \\ RALPH U. WHITTEN**
}

Nearly a quarter of a century ago, Professor Charles L. Black attempted to give some direction to the development of admiralty jurisdiction by suggesting some innovative jurisdictional rules. ${ }^{1}$ The suggested rules were, in his opinion, more rational than the old, which were in reality inherently uncertain and impractical ${ }^{2}$ and thus failed to possess the utility which their apparent simplicity would suggest. Moreover, his suggested tests were preferable because they included things within admiralty jurisdiction which "ought" to be there instead of mechanically leading to illogical results as did the existing rules. The specific content of Professor Black's suggested tests is not directly related to our inquiry, since he was concerned with the whole of the admiralty power and attempted to articulate a definition of the entire jurisdictional scope of a separate constitutionally created special court - a "sort of one-industry Tribunal of Commerce."3 Our fundamental concern is only with admiralty jurisdiction in tort cases. However, our inquiry has the same objective as Professor Black's broader undertak-

* Assistant Professor of Law, University of South Carolina. A.B. 1967, Midwestern University; J.D. 1970, Southern Methodist University; LL.M. 1971, Harvard University.

** Assistant Professor of Law, University of South Carolina. B.B.A. 1966, J.D. 1969, University of Texas; LL.M. 1972, Harvard University. The authors are indebted to Miss Katherine Hill for her research assistance on this article.

1. Black, Admiralty Jurisdiction: Critique and Suggestions, 50 Colum. L. Rev. 259 (1950).

2. Consider, for example, Professor Black's basic arguments against the old locality test for admiralty tort jurisdiction:

Since a "tort" a mental construction, doesn't "take place" anywhere, the application of this "test" gives rise to an open series of "and-now-what-if's," remimiscent intellectually of those discussions of fine points in the law of keeping bees which once rang through the Halls of Tara, and pictorially of the Marx Brothers running up and down gang planks one jump ahead of the cops. But the "test" is subject to the nuuch noore fundamental objection that it refers, however imperfectly, to arbitrary locahity rather than to real and practical relation with the business and commerce of the sea. Id. at 264.

3. Id. at 276. Professor Black suggested that admiralty jurisdiction should extend

[i]n tort, [to] all those cases seeking rehief for tortious conduct with respect to the subject-1natter of [business arrangenients concerned primarily with sea, lake, and river transport], or for injuries by or to vessels or other maritime objects, or injuries to persons taking place in connection with the conduct of the business of shipping. Id. at 274. 
ing-to identify the incongruities and deficiencies in current jurisdictional rules, and to formulate a reasonable rule which will operate with more predictability and produce results compatible with the substantive policies of admiralty law. ${ }^{4}$

We propose to identify the features which we think any "good" jurisdictional rule should possess-in admiralty or elsewhere-as well as features which accommodate the specialized needs of the admiralty area. To that end, we think that any good jurisdictional test should achieve two distinct results: first, the test should be clear enough to avoid unnecessary litigation over the procedural formulation of the jurisdictional rule at the threshold of the lawsuit, which is to say that the basic mechanism of the rule should be clear. The need for clarity seems obvious: litigation concerning application of the jurisdictional rule is wasteful simce it rarely advances the substantive rights of the disputants. Second, because jurisdictional provisions are the handmaidens of the substantive law, jurisdictional tests should focus upon all and only those factors relevant to the existence of the jurisdiction. Recently, the Supreme Court of the United States in Executive Jet Aviation v. City of Cleveland ${ }^{5}$ took an important step toward the goal of creating a coherent rule for admiralty tort jurisdiction. Nevertheless, it will be argued that the Executive Jet decision falls considerably short of meeting the desirable standards for a complete jurisdictional rule.

It is clear that the Supreme Court in Executive Jet adopted a new approach by rejecting the old locality test for admiralty tort jurisdiction. At the same time, the Court did not completely abandon that test. Under the old locality test for admiralty tort jurisdiction announced by Joseph Story in $1813,{ }^{\circ}$ the place where the tort occurred was exclusively determinative of admiralty jurisdiction and the applicability of admiralty law. Since the jurisdiction of the admiralty court originated in a constitutional grant of limited and specialized powers, ${ }^{7}$

4. See note 142 infra.

5. 409 U.S. 249 (1972).

6. See Executive Jet Aviation, Inc. v. City of Cleveland, 409 U.S. 249, 253 (1972); Victory Carriers, Inc. v. Law, 404 U.S. 202, 205 (1971); Thomas v. Lane, 23 F. Cas. 957 (No. 13,902) (C.C. Me. 1813), cited in Askew v. American Waterways Operators, Inc., 411 U.S. 325, 340 (1973). Justice Story stated:

In regard to torts I have always understood, that the jurisdiction of the admiralty is exclusively dependent upon the locality of the act. The admiralty has not, and never (I believe) deliberately claimed to have any jurisdiction over torts, except such as are maritime torts, that is, such as are committed on the high seas, or on waters within the ebb and flow of the tide. Thomas v. Lane, 23 F. Cas. 957, 960 (C.C. Me. 1813).

7. The power of the federal district courts to hear "all cases of admiralty and maritime jurisdiction" represents a unique attempt within the federal system to establish a separate, specialized tribunal as prescribed by the United States Constitution and im- 
plemented by statute. U.S. CoNST. art. III, $\$ 2$. For the statutory enactments vesting the district courts with this constitutionally delineated power, see 1 Stat. 76-77 (1789); 28 U.S.C. $\S 1333$ (1970). The district courts, by the Judiciary Act of 1789, were granted "exclusive original cognizance of all civil causes of admiralty and maritime jurisdiction . . . saving to suitors, in all cases, the right of a common law remedy, where the common law is competent to give it . . . " It is important to note that the "saving to suitors" clause in no way limits the power of the federal courts to lear cases falling within the jurisdictional grant, but merely "allows, to a limited extent, application of the coinnon law." Note, Admiralty Jurisdiction: Executive Jet in Historical Perspective, 34 OHio St. L.J. 355, 357 (1973). Further, the jurisdictional grant carries with it a rulemaking power which permits the creation of substantive rules of law by the federal courts, and which preempts state law when exercised. Southern Pac. Co. v. Jensen, 244 U.S. 205 (1916). Of course this presumptive rulemaking power extends only so far as Congress has from time to time extended jurisdictional competence to the federal courts by enacting statutes to inplement article $\mathrm{II}$, section 2 of the Constitution. Exactly low far Congress has gone in extending this competency has historically been the subject of much debate, scholarly comment, and confusing case law. Much has been written concerning this question and the historical developinent of admiralty jurisdiction generally as it relates to essential questions of federalism, strategic advantages accruing to litigants in adiniralty jurisdiction, and a host of other factors.

The historical development of the admiralty jurisdiction, particularly as viewed from the standpoint of judicial reasoning about the extent of the potential admiralty powers vested in the federal courts at any given time, sheds much liglt on the magnitude of this issue. Basically, the American Revolution and the creation of the federal system resulted in a monopoly of the admiralty powers by the federal courts pursuant to article III, section 2 of the Constitution. This produced a number of significant results. First, it freed the federal courts from even the rather negligible restrictions which had been previously placed upon American admiralty tribunals, principally through colonial legislative adoption of English statutory restrictions on admiralty jurisdiction. Several ancient restrictive Parliamentary enactments had been made of force in the colonies by specific adoption. For example, for the provisions in force in South Carolina, see 2 Stat. of S.C. 446 (Cooper ed. 1837), which sets out the text of a colonial enactment of 1712 adopting the statutes of 13 Ricl. II, c. 5 (1390), and 15 Rich. II, c. 3 (1392). These ancient English statutes were at the heart of centuries of debate about the scope of admiralty jurisdiction in England. Though the fimal result of the jurisdictional struggie differed according to the subject matter involved, e.g., maritime contracts as opposed to torts, the statutes ultimately came to be interpreted by the English common law courts as establishing the "infra corpus comitatus" rule for tort jurisdiction. This made the sloreside boundaries of the counties the point where the admiralty jurisdiction ended and the common law jurisdiction began, regardless of the essential maritime significance of the tort mvolved in any given case. The resultant narrowing of the competency of the English admiralty courts, brought about largely by the sustamed competition and hostility of the common law courts, lasted until well after the American Revolution. The restricted nature of English admiralty jurisdiction was, however, in contrast to the relatively more extensive powers exercised by colonial vice admiralty courts. For an excellent discussion of the background of the American admiralty jurisdiction established by the U.S. Constitution, see D. ROBERTSON, ADMIRALTY AND FEDERAlism 28-64 (1970). Significantly, the federal monopoly created by the Constitution resulted in a rather thoroughgoing rejection of the English jurisdictional limitations. This development was supported in large part by the listorically questionable assumption, ultimately adopted by the federal courts, that a broad interpretation of article III, section 2 of the Constitution was consistent with the previous, almost unfettered, powers of colonial admiralty tribunals, and was thus also consistent with the intent of Congress in their treatment of admiralty powers in the original Ju- 
this test has traditionally been strictly construed. ${ }^{8}$ So unwilling were the courts of the admiralty to extend their jurisdiction to include maritime-related tonts occurring near but not upon the navigable waters that a congressional act was required to extend the admiralty jurisdiction to include torts caused by maritime vessels when the situs of the tort was on the land or an extension thereof. ${ }^{\circ}$ Prior to Executive Jet

diciary Act. See D. RoberTson, supra, at 65-103.

In the American case law, the "tidewater limitation," which was a product of the ongoing struggle between English admiralty and the common law courts, was initially adopted in The Steamboat Thomas Jefferson, 23 U.S. (10 Wheat.) 428 (1825). This rule limited the extent of the admiralty jurisdiction exercised by the federal courts to waters within the ebb and flow of the tide. This test was subsequently stretched beyond any rational application in Waring v. Clarke, 46 U.S. (5 How.) 441 (1847), which held that the ebb and flow of the tide affected waters on the Mississippi River over two hundred miles from the ocean. Federal policy, as opposed to empirical analysis, clearly emerged as the basis for the jurisdictional test with the ultimate rejection of the tidewater doctrine by the Supreme Court in the case of Genessce Chief v. Fitzhugh, 53 U.S. (12 How.) 443 (1851). The holding of Genessee Chief was superficially predicated upon a congressional statute of 1845, 5 Stat. 726 (1845), granting the federal courts jurisdiction over certain causes arising on the Great Lakes, and was arguably merely a congressional atteinpt to expand the then undistributed jurisdictional competency beyond that granted to the federal courts by the Judiciary Act of 1789. The Genessee Chief decision has, however, come to be regarded as a conscious attempt to define the extent of admiralty power originally granted to the federal courts under the 1789 Act, and thus as a definition of the jurisdictional rule for all waters subject to federal power. The case has, probably correctly, been interpreted as a fundanental rejection of previous limitations on the original jurisdictional grant of 1789. See D. RoBERTSON, supra, at 115-17.

Genessee Chief extended admiralty jurisdiction, with its concomitant rulemaking competency, to all waters of the United States navigable in interstate or foreign commerce. Out of this situation emerged the "locality test" for tort jurisdiction, which was utilized over the years to refine concepts of situs pertaining to torts and their physical relationship to bodies of water qualifying under the navigability test. This rule, we contend, has often skewed the basic substantive considerations supporting the application of admiralty law.

For other literature dealing with the historical development of admiralty jurisdiction in both England and America in addition to the above cited authorities, see G. GILMORE \& C. BLACK, THE LAW OF ADMTRALTY 1-47 (1957); D. ROBERTsON, supra, at 35 n.32 and sources collected therein; F. WisWaLl, THE DEVELOPMENT of ADMmaLty JUrisdiction and Practice Since 1800, AN ENGLish StUdy with AMERican Comparisons (1970), reviewed in 16 AM. J. LEGAL Hist. 274 (1972); Mears, The History of Admiralty Jurisdiction, in 2 SELECT ESSAYS IN ANGLO-AMERICAN LEgAL HISTORY 312 (1908); Note, From Judicial Grant to Legislative Power: The Admiralty Clause in the Nineteenth Century, 67 HaRv. L. REv. 1214 (1954).

8. See The Plyinouth, 70 U.S. (3 Wall.) 20, 35-36 (1865).

9. The Adiniralty Extension Act, 46 U.S.C. $\$ 740$ (1970), was passed in 1948 specifically to overrule the strict interpretation of the locality test which had been promulgated in The Plynouth, 70 U.S. (3 Wall.) 20 (1865). The Act provided in part:

The admiralty and maritime jurisdiction of the Umited States shall extend to and include all cases of damage or injury, to person or property, caused by a vessel on navigable water, notwithstanding that such damage or injury be done or consummated on land. 
the old locality test had been invoked rather mechanically. In Weinstein v. Eastern Airlines, Inc., ${ }^{10}$ it was invoked to create admiralty jurisdiction on behalf of the claims of the representatives of the victims of an airline tragedy which took place in Boston harbor. The court concisely explained the traditional rule it employed: "If the tort occurred on navigable waters, the claim is one that lies within the jurisdiction of the courts of admiralty; nothing more is required."11 It was this construction of the rule that the Supreme Court in Executive Jet clearly rejected.

However, what the Supreme Court placed in the old rule's stead is much less clear. The Court in Executive Jet formulated some sort of a "locality plus" rule for admiralty jurisdiction:

[W] conclude that the mere fact that the alleged wrong "occurs" or "is located" on or over navigable waters-whatever that means in an aviation context-is not of itself sufficient to turn an airplane neghgence case into a "maritime tort." It is far more consistent with the history and purpose of admiralty to require also that the wrong bear a significant relationship to traditional maritime activity. We hold that unless such a relationship exists, claims arising from airplane accidents are not cognizable in admiralty in the absence of legislation to the contrary. ${ }^{12}$

It cannot be disputed that, in the Court's view, locality is still a part of the test for admiralty jurisdiction, since the Count cites the existing locality test with some approval in the initial portion of its opinion. ${ }^{13}$ However, it is not made explicit what the role of locality is specifically intended to be. Furthermore, as close as the Court comes to a precise statement of what it means to have a "sufficient relationship to traditional maritime activity" in the context of aviation disasters is found in its criteria that the airplane at the time of the accident "be performing a function traditionally performed by waterborne vessels." 14 Thus, under the current test, both locality plus a maritime reJationship, or nexus, anust in some unspecified form, exist. Olearly such a formulation of the jurisdictional rule is itself bound to produce

10. 316 F.2d 758 (3d Cir.), cert. denied, 375 U.S. 940 (1963).

11. Id. at 761 (emphasis added; footnote omitted).

12. 409 U.S. at 268.

13. Id. at 253-54. "The Court has often reiterated this rule of locality." See also Watson v. D/S A/S Idaho, 359 F. Supp. 496, 499 (E.D. Pa. 1973); Maryland v. Amerada Hess Corp., 356 F. Supp. 975, 976 (D. Md. 1973); 4 J. MARrTIME L. \& CoM. 637, 642 (1973).

14. 409 U.S. at 271. For example, a helicopter can perform the functions of a crew boat for an offshore oil platform. See Higginbotham v. Mobil Oil Corp., 357 F. Supp. 1164 (W.D. La. 1973) and text accompanying notes $97 \& 98$. 
confusion, both in respect to the meaning of its constituent elements and its operation in practice.

Therefore, we contend that the rule as stated by the Supreme Court fails to establish understandable guidelines and that it will therefore produce the very results which the Court sought to avoid by abandoning the strict locality test: a test filled with "perverse and casuistic borderline situations."15 We also assert that meaningful guidelines for a more rational jurisdictional test can be found in the existing jurisdictional trends in non-admiralty areas. We therefore propose (i) to analyze the antecedents of the Executive Jet decision, (ii) to analyze the rule announced in Executive Jet by considering the possible interpretations of the rule, (iii) to examine the apphication of the rule in subsequent cases to illustrate the uncertainty of the new test, and (iv) to indicate those features of admiralty law, both jurisdictional and substantive, which have caused this uncertainty. We shall then propose an alternative rule designed to eliminate these defects by associating the exercise of admiralty jurisdiction with identifiable maritime concerns such as torts committed by the performers of maritime functions, rather than with the illusory test of locality alone.

\section{Pre-Executive Jet Overtures Toward the CREation OF A NEW RULE}

The first difficulty in analyzing the new jurisdictional rule of $E_{x \text { - }}$ ecutive Jet arises with the failure of the Court to clarify the ambiguities in the case law which it purported to follow. It therefore becomes useful to examine the primcipal federal cases anticipating the decision in Executive Jet and to analyze briefly both the manner in which they sought to depart from the strict locality rule as well as the method which they used in applying the new tests which they created. It is in methodology that the most apparent aunbiguity of the Executive Jet rule has its genesis.

Fundamental to understanding Executive Jet is Chapman v. City of Grosse Pointe Farms. ${ }^{16}$ In Chapman, the plaintiff dove from a recreational pier owned by the city, imjuring himself in the shallow adjoining waters. The plaintiff alleged that the city had been negligent in failing to erect sufficient barriers or warning signs along the

15. 409 U.S. at 255.

16. 385 F.2d 962 (6th Cir. 1967). This case was relied upon by the district court in the Executive Jet litigation. See 409 U.S. at 251. See generally Peytavin v. Gov. ernment Employees Ins. Co., 453 F.2d 1121 (5th Cir. 1972); Gowdy v. United States, 412 F.2d 525 (6th Cir.), cert. denied, 396 U.S. 690 (1969); Note, New Guidelines for Admiralty Tort Jurisdiction, 48 IND. L.J. 87 (1972). 
pier. ${ }^{17}$ Following a dismissal for want of jurisdiction by the district court, the Court of Appeals for the Sixth Circuit was presented with two questions of law arising out of the case. The first involved the difficulty inherent in determining the actual situs of the tort, since in borderline cases in admiralty jurisdiction it is often the case that the place of the injury is indefinite, as "a claimant has usually suffered some mjurious impact upon both land and water."18 After citing language froin two not entirely consistent cases, Minnie v. Port Huron Terminal Co. ${ }^{19}$ (which stands for the classical "consummation test," that is, that the place of the tort is located at the place of actual injury) and Thomas v. Chesapeake Yacht Club, Inc. ${ }^{20}$ (which held that the place of the tort is found at the point where the negligence "becomes operative or effective on the plaintiff"21), the Chapman court held in effect that when the tortious conduct is integrally related with some action in or on navigable waters, rather than with conduct which is only fortuitously related to some adjacent body of water, the place of the tort is found to be within the sphere of admiralty jurisdiction. ${ }^{22}$ Second, the court entertained the question whether the libel at bar by its nature was suitable for treatment under the law of admiralty in federal court. Holding that "it might be said that some relationship between the alleged wrong and maritime service, navigation or commerce on navigable waters, is a condition sub silentio to admiralty jurisdiction," 23 the count of appeals departed from the majority view regarding such cases, ${ }^{24}$ and held that some maritime element is required

17. 385 F.2d at 963.

18. Id. at 964 .

19. 295 U.S. 647 (1935), cited in Chapman v. City of Grosse Point Farms, 385 F.2d at 964 . In Minnie, a longshoreman was struck by a cargo hoist while working on the deck of a vessel. The conrt concluded that admiralty jurisdiction was present by applying a rule focusing on the place where the injnry was received. 295 U.S. at 648.

Oddly enough, the very same rule had operated in a previous case to deny jurisdiction where the injured party, a longshoreman, happened to be standing on a pier when he was struck by a cargo sling from a ship. See T. Smith \& Son v. Taylor, 276 U.S. 179 (1928). See generally Executive Jet Aviation, Inc. v. City of Cleveland, 409 U.S. 249,255 (1972).

20. 255 F. Supp. 555 (D. Md. 1965), modified, 66 A.M.C. 2275 (1966).

21. 255 F. Supp at 558.

22. 385 F.2d at 965. See, e.g., The Admiral Peoples, 295 U.S. 649 (1935) (admiralty jurisdiction upheld over a case where the plaintiff stumbled upou a faulty gangplank negligently maintained by the defendant shipowner). The place where the injuries were fortuitously consummated-on land, i.e., the pier-was considered irrelevant, since the negligent act had affected the plaintiff through an appendage of the vessel. Id. at 651-52.

23. 385 F.2d at 966 .

24. See 409 U.S. 249,256 n.5 where cases following the literal application of the 
in addition to locality in order to sustain admiralty jurisdiction and that swimming did not provide such a maritime connection.

A careful analysis of the ways in which the counts have treated the two elements of "locality" and "maritime connection" in the admiralty jurisdiction test, however, reveals the problems inherent in its application and the prevailing lack of certainty about just what the jurisdictional rule is. Unfortunately, the recent jurisdictional developments lrave neither dispelled this uncertainty nor given rise to a welldefined jurisdictional rule. The Chapman count clearly considered the rule to be a test involving "locality plus." The court stated:

While the locality alone test should properly be used to exclude from admiralty courts those cases in which the tort giving rise to the lawsuit occurred on land rather than on some navigable body of water, it is liere determined that jurisdiction may not be based solely on the locality criterion. ${ }^{25}$

Despite the court's skepticisin that a maritime nexus ever existed in the case, the court did specifically reach the locality issue and thus adhered to a procedural view of the jurisidctional rule which would require a determination of both the locality of the tort and the maritime relationship. A martime locality was found largely because the conduct of the plaintiff had been voluntarily and intentionally related to a navigable body of water. ${ }^{26}$ "Voluntariness," however, is scarcely a definitive concept, since what one intends and what is fortuitous are not always separable or distinguishable. Having determined that a maritime locality existed, however, the court was further unclear as to what the functional requirements of a maritime relationship might be, and thus merely stated that "[a] relationship must exist between the wrong and some maritime service, navigation or commerce on navigable waters." ${ }^{27}$ Exactly which aspects of the lawsuit must be so related was not clarified. Yet the possibilities are numerous-for example, must the defendant or the negligent act or acts which he commits be associated with traditional maritime concerns and be causally related to the plaintiff, or must the plaintiff be involved in maritime activities, or both? Must the itype of injury received, once locality is satisfied, also be one which is mormally associated with maritime mat-

locality rule are collected by the Supreme Court. "In cases such as these, some courts have adhered to a strict locahity rule and have sustained admiralty jurisdiction despite the lack of any connection between the wrong and traditional forms of maritime commerce or navigation." Id. at 255-56.

25. 385 F.2d at 966.

26. Id. at 965 .

27. Id. at 966 . 
ters? In shont, though the holding of the case was clear in its result, the only clear resolution of the rule's content concerned the fact that locality may be used as an exclusionary factor in the jurisdictional test. Ironically, even this aspect of the test has currently been eroded.

The clear division of the jurisdictional rule by the Chapman court into two stages, locality and nraritime nexus, and the court's explanation, however brief, that the locality elenient is a necessary but not an independently sufficient factor in the jurisdictional test is significant in light of the earlier "maritime nexus" case upon which the Chapman court relied even though it suggested an approach to the locality rule shightly different from that used in Chapman. McGuire v. City of New Yor $k^{28}$ presented a jurisdictional issue involving a swimmer injured in the shallow waters of a public bathing beach owned and operated by the City of New York. The plaintiff injured her hand on a submerged object in the waters of the beach and attempted to invoke admiralty jurisdiction. The court seemingly advocated an approach to the locality rule similar to that charted by the Chapman court, stating that the fact that a tort "may have occurred on navigable waters is merely a prima facie test of admiralty jurisdiotion," 29 and that the locality test "was developed as a rule of limitation, as a means of limiting the scope of adminalty jurisdiction."30 However, rather than deciding whether the case could be excluded on the basis of the locality issue alone, the court argued that it could justifiably ignore the locality question altogether, ${ }^{31}$ since the case could be entirely settled by finding the absence of a "maritime wrong." 32 Citing a nineteenth century English case for its fundamental approach, ${ }^{33}$ the court argued:

You have to consider three things-the locality, the subject matter of the complaint, and the person with regard to whom the complaint is made. You must consider all these things in determining whether the

28. 192 F. Supp. 866 (S.D.N.Y. 1961).

29. Id. at 870 .

30. Id. at 869 . The court's dissatisfaction with the locality test as a complete test was based on the view that the locality test "is subject to the much more fundamental objection that it refers, however imperfectly, to arbitrary locality rather than to the real aud practical relation with the business and commerce of the sea." Id. at 870, quoting Black, supra note 1, at 274.

31. The court expressed doubt that the shallow waters of the beach were navigable "in the ordinarily accepted sense of the word." $192 \mathrm{~F}$. Supp. at 867. This differs from the procedure employed by the Chapman court, which proceeded to rule on locality before determining maritime nexus, even though, as in McGuire, the court felt that no maritime nexus existed.

32. "The basis for admiralty jurisdiction must be a combination of a maritime wrong and a maritime location." Id. at 868.

33. The Queen v. Judge of the City of London Court, [1892] 1 Q.B. 273. 
Admiralty court has jurisdiction . . . . But, if any of the three matters is wanting, the Admiralty court may not have jurisdiction. ${ }^{34}$

Focusing upon the nature of subject matter of the complaint, the court considered whether the tort in the case involved any conventional maritime eleinent. ${ }^{35}$ In atteinpting to state some organizing principle for the application of admiralty law, the court stated that "[a]dmiralty law is, in fact the law of commerce," ${ }^{36}$ and that " $\left.t\right]$ he proper scope of jurisdiction should include all matters relating to the busmess of the sea and the business conduoted on navigable waters." ${ }^{37}$ The libel concerned in the case did not, in the court's opinion, "relate to any tort which grows out of navigation," 38 and therefore failed.

At first glance the jurisdictional approaches in McGuire and Chapman seein consistent. Both considered the rule to be one necessitating "locality plus." Yet, as a inethod of applying the jurisdictional rule, the Chapman court chose to nake a clear finding of locality before proceeding to evaluate the maritime element in the case. On the other hand, the McGuire court viewed the locality test as a "rule of limitation" and clearly relegated it to secondary importance by moving immediately to consider the substantive element of the actionthe maritime relationship. Moreover, the courts differ on their understanding of what constitutes a maritime relationship: The McGuire court employed a test that described the "involvement" of a martime matter in vague, but limited, terms of whether or not a conventional maritime agency either caused the alleged liarm or was harmed. The

34. 192 F. Supp. at 867.

35. "A maritime wrong generally has been concluded to be one which in some way is involved in shipping or commerce." Id. at 868-69. The maritime matters described by the court predominantly included mstrumentalities of maritime activity or commerce, in particular vessels or conventional maritime instrumentalities in tort cases. Id. at 870 .

The court viewed with approval Professor Black's suggestion that the jurisdictional rule should therefore cover:

(1) In contract, all those cases involving the enforcement, policing, or adjustment of business arrangements as a practical matter primarily concerned with sea, lake, and river transport.

(2) In tort, all those cases seeking relief for tortious conduct with respect to

the subject matter of (1), or for injuries by or to vessels or other maritime objects, or injuries to persons taking place in connection with the conduct of

the business of shipping. Id., quoting Black, supra note 1, at 274.

The court also showed deference to other authorities which tended to describe the maritime character of a cause of action in terms of the involvement of vessels or navigation. 192 F. Supp. at 871, citing G. RoBINSON, ADMIRALTY, \$\$ 8.9 (1939); 1 E. BENEDICT, ADMIRALTY \$ 61 (6th ed. 1940).

36. 192 F. Supp. at 871.

37. $I d$.

38. Id. 
court rather obtusely suggested that the rule should only embrace injuries to persons taking place "in connection with the conduct of the business of shipping," ${ }^{39}$ which could possibly include maritime agencies other than vessels if they in fact had caused the injury. In short, the focus of the court's test was upon the identification of some arguably inaritime cause of the injury, and the strong suggestion is that. this should be accomplished by a rather strict analogy to maritime instrumentalities engaged in maritime busmess. This test, while unclear, is certainly narrower than that announced in Chapman. Specifically, McGuire entails that the "maritime nexus" or "maritime relationship" does not embrace a "totality of circumstances" test and thus could not ever result in the exclusion of a "non-maritime" plaintiff from admiralty jurisdiction, so long as a maritime agency such as a vessel caused his injury. This implies that jurisdiction inust be denied only if the defendant is not sufficiently identified with a maritime activity in the traditional sense, and it therefore suggests that the real meaning of the relationship or nexus requirement concerns the establishment of a chain of injury-producing causation running from a maritime defendant to the plaintiff. The establishment of a causal connection between a maritime defendant and any plaintiff would likely satisfy the instrumentality test of $M c G$ Guire. To this extent the functional aspects of the maritime relationship or nexus test are stated with a greater degree of specificity in McGuire than in Chapman, though the results in the two cases are adequately reconcilable.

Thus, even before Executive Jet, different aspects of a new rule were emerging. These various aspects served to establish the significance locality would assume in that new rule and, inore importantly, helped to define the approach to be used in determining whether the required nuaritime relationship exists. Whether the maritime nexus rule is essentially a rule focusing on the defendant, as opposed to an exclusionary rule apphed to non-inaritime plaintiffs, was emerging as a question which logically would come to play an important part in determining the extent to which the new jurisdictional test satisfies the objective of associating admiralty jurisdiction with "true" maritime matters and the extent to which it is consistent with the substantive principles of admiralty law. Furthermore, the clarity of the emerging rule was being clouded by variations in the application of the locality requirement-whether it is (1) a determination to be made first, regardless of any apparent presence or absence of maritime nexus, (2) to be ignored if maritime nexus is doubtful, or (3) to be decided only

39. Id. at 870 , quoting Black, supra note 1 , at 274. 
if the nexus does exist. Nevertheless, before Executive Jet, the emerging rule had not been cast into functional terminology, and the importance of these funotional issues in the jurisdictional rule had unfortunately remained a negleoted aspect of the gradual process of abandoning the old test of strict locality.

\section{Executive Jet: Formulation OF THE NEW RULE}

Despite these deficiencies in the emerging new jurisdictional rule, the Supreme Court in Executive Jet did not adequately address itself to the failure of the previous definitions to structure a jurisdictional rule which reflects the concepts and functions of maritime enterprise.

In Executive Jet an airplane ingested some seagulls into its jet engines while attempting to take off from a Cleveland airport. The plane had been cleared for takeoff by the traffic controller but, due to the imgestion of the birds, almost completely lost power and attempted to return to the airfield. But the plane veered off course and struck an airport perimeter fence and a parked truck, finally settling into the nearby waters of Lake Erie about a fifth of a statute mile off shore. The aircraft owners, asserting admiralty jurisdiction, sued the air traffic controller, the City of Cleveland as owner and operator of the airport, and the airport manager. ${ }^{40}$

Each of the courts treated these facts differently. The district court, relying principally on Chapman, held that the rule was "locality plus" rather than the traditional locality rule. The court's defimition of the rule required a determination that the location of the tort was on navigable waters, as well as "a relationship between the wrong and some maritime service, navigation or commerce on navigable waters." ${ }^{11}$ The district court felt that neither criterion was satisfied and, similar to the Chapman court (which it purported to follow), made findings on both looality and maritime relationship. The court used a traditional test to determine locality, focusing upon the place at which the negligence becarne effective or "operative" upon the plaintiff, 42 as opposed to the place where the injury was consummated. ${ }^{43}$ In this

40. 409 U.S. at $250-51$.

41. Id. at 251.

42. The court found that

the alleged negligence became operative upon the aircraft while it was over the land; and in this sense the "impact" of the alleged negligence occurred when the gulls disabled the plane's engines [over the land] ..... From this point on the plane was disabled and was caused to fall. Whether it came down upon land or upon water was largely fortuitious. Id. at 251-52.

43. The various locality tests are thoroughly discussed in Thompson v. Chesapeake Yacht Club, Inc., 255 F. Supp. 555 (D. Md. 1965). Generally, the various tests are 

fied, the court made separate findings on both issues, indicating that the finding of either might give rise to admiralty jurisdiction. But the Sixth Circuit Court of Appeals affirmed on the locality point alone, holding that the tort occurred over land, and that it was unnecessary to consider the maritime relationship requirement. ${ }^{45}$

When the case came before the Supreme Court, the Court was faced with the task of reviewing departures from the historical rules undertaken by both the lower courts. ${ }^{46}$. The fundamental question was, should the test be inore than mere locality? Rather than inake a determination on both locality and maritime relationship, as the district court had done, or approach locality as a threshold question, a negative answer to which would preclude the maritime relationship question, as the court of appeals had done, the Court moved directly to consider the maritime nexus question. In doimg so, instead of providing a clear jurisdictional rule, the Court simply anade the role of locality in the new test ambiguous. For example, the Court proceeded by describing situations where the old locality rule produced "absurd" and inconsistent results. The Court took some pains to document the seemingly irrational treatinent of different plaintiffs whose maritime status or importance was virtually identical but who received different jurisdictional treatment based on strictly spatial considerations. ${ }^{47}$ After citing Chapman with approval, which might have imdicated an approval of the Chapman approach to the application of the jurisdictional rule, ${ }^{48}$ the Supreme Court proceeded to decide the Executive Jet controversy in a manner which gave little guidance concerning how to apply the various aspects of the test to different fact situations. The Supreme Court averred that it had never really "explicitly held" that the maritime locality requirement was the sole test of admiralty jurisdiction, miplymg that the test could be made to include some additional requirement without doing violence to the old concept. ${ }^{40}$ As further evidence of the Court's dissatisfaction with the often irrational results produced by the old locality rule, it mentioned other areas where the maritime significance of a particular subject nnatter had

45. Id.

46. The district court had turned to the "locality plus" formulation of the rule; the court of appeals had rejected the rule of convenience traditionally accepted in determining the location of the tort in aircraft accident cases.

47. See 409 U.S. at 254. The court compares T. Smith \& Son v. Taylor, 276 U.S. 179 (1928), with Minnie v. Port Huron Terminal Co., 295 U.S. 647 (1935). See note 43 supra.

48. 409 U.S. at 256. See Onley v. South Carolina Elec. \& Gas Co., 488 F.2d 758, 760 (4th Cir. 1973).

49. 409 U.S. at 258. 
persuaded Congress to bestow admiralty jurisdiction on the federal courts in cases where the locality requirement was clearly unsatisfied. ${ }^{50}$ However, the Court did not clarify the way in which some additional requirement might be applied. In fact the language of the Court at one point might be read as indicating that the maritime nexus test should stand in lieu of the locality test in certain instances. Specifically, the Court stated:

In sum, there had existed over the years a judicial, legislative, and scholarly recognition that, in deternining whether there is admiralty jurisdiction over a particular tort or class of torts, reliance on the relationship of the wrong to traditional maritine activity is often more sensible and more consonant with the purpose of maritime law than is a purely mechanical application of the locality test. ${ }^{51}$

However, throughout its opinion the Court also speaks of problems with the "locality alone" test, ${ }^{52}$ suggesting that some role for locality is retained, but with an additional requirement of maritime nexus. Unfortunately, the Court's resolution of the case leaves the role of locality undefined, for it considered the conflicting interpretations of the locality of the tort urged by the litigants ${ }^{53}$ but decided that in the absence of a maritime nexus in aircraft accidents of this sort it was unnecessary to decide the locality question at all. ${ }^{54}$ The Court stated that the inere fact that the alleged wrong "occurs" or "is located" on or over navigable waters-whatever that ineans in an aviation context -is not itself sufficient to turn an airplane negligence case into a "maritime tort." It is far more consistent with the history and purpose of admiralty to require also that the wrong bear a "significant relationship to traditional maritime activity." ${ }^{\text {" }}$ This language, coupled

50. Id. at 259-60. The Court here referred to the Jones Act, 46 U.S.C. $\S 688$ (1970), which allowed admiralty jurisdiction over land-based injuries to seamen. The Court also discussed traditional admiralty law doctrines covering land-based injuries, such as unseaworthiness and maintenance and cure. The former extended to shoreside injuries caused to longshoremen stemming from defects in a ship or its gear and the latter covered seamen wherever they might go. Also the Extension of Admiralty Jurisdiction Act, 46 U.S.C $\$ 740$ (1970), providing admiralty jurisdiction for damages to shore property caused by vessels on navigable waters, evidenced concern for rationally associating the inposition of admiralty power with the acts of a truly maritime agency.

51. 409 U.S. at 261.

52. Id. at 265-68.

53. Id. at 267.

54. "In the view we take of the question before us, we need not decide who has the better of the dispute. It is enough to note that either position gives rise to the problems inherent im applying the strict locality test of admiralty tort jurisdiction in aviation accident cases." Id.

55. Id. at 268.

56. Id. 
with the reliance on Chapman and the continuous references to the "locality alone" test or locality as the "sole test," would seem to imply that the Court attempted to create a "locality plus" test, rather than an outright abandonment of the locality test. The application of the new rule, however, did not in the Court's opinion necessitate a finding of locality where the required maritime nexus was absent. Thus, the locality question would only be reached as a further exclusionary test if the threshold maritime nexus were present.

Confronting the question whether a nexus existed between the libel and a maritime activity, the Court concluded that no nexus could be sustained where interstate flights, beginning and ending within the continental United States, bear no significant relationship to maritime travel or other maritime activity. ${ }^{57}$ The Court then focused upon the nature of the plaintiff involved in the suit and concluded that the plaintiff was not sufficiently connected to any maritime activity to justify the assertion of jurisdiction.

Although the Supreme Court and many observers believe that the result of Executive Jet may have sensibly avoided the application of admiralty law to an intracontinental aviation accident, the method used for disposing of the case lias resulted in unuch confusion about the vitality of the locality rule and its precedence in application, if it is still a part of the test at all. Indeed, it has been held by at least one court that there has been no change from the strict locality rule at all, save in aircraft accident cases. ${ }^{58}$ The courts following Executive Jet have also not exhibited a uniform acceptance of the functional analysis utilized by the Supreme Court to establish the nature and function of the plaintiff and the injury-causing activity.

\section{The Post-Executive Jet Opintons: Problems With the RULE AS APPLIED}

In attempting to articulate the defects in the Executive Jet mode of jurisdictional decision, as well as in attempting to formulate a workable alternative, several of the principal post-Executive Jet decisions will be reviewed to illustrate again that the jurisdictional rule after $E x$ ecutive Jet may still be the subject of much confusion among the fed-

57. After assessing possible comparisons between the condition of a plane or its passengers in cases where the plane has crashed at sea, the Court was persuaded that the differences between airplane travel and travel by a conventional vessel outweighed such similarities, and the different sources and concepts of regulation in the two areas militated against equating these methods of travel. Id. at 269.

58. Watson v. D/S A/S Idaho, 359 F. Supp. 496, 499 (E.D. Pa. 1973). 
eral courts. The rule has not proved to be the least bit lucid, and district court judges on occasion have been forced to request counsel to submit briefs just to determine the effect of Executive Jet upon a case which would otherwise have been treated without hesitation under admiralty jurisdiction. ${ }^{59} \mathrm{~A}$ critical look at the lower court decisions following Executive Jet will illustrate the various molds into which the new rule may be cast and will hopefully also illuminate an organizing principle which will assist in defining a rule which can be effectively applied to all cases without incongruous results.

The possible rules generated by Executive Jet include the following: (1) The old locality rule prevails as always except in specifically excepted areas, such as aircraft accidents. ${ }^{60}$ (2) The old locality rule prevails as always except in the specifically exempted areas and in cases sufficiently similar to exempted areas, e.g., aircraft accidents arising in intracontinental flights, and not satisfactorily capable of resolution by the inechanical operation of the traditional locality rule. ${ }^{61}$ (3) The locality test has been flatly rejected, leaving the fimding of a sufficient maritime nexus as the only relevant criterion for admiralty jurisdiction. $^{62}$ (4) The test demands a finding of both locality and a maritime nexus, the failure to find either being capable of defeating the jurisdiction. ${ }^{63}$ Under one formulation of this test the court may

59. Oppen v. Aetna Ins. Co., 485 F.2d 252 (9th Cir. 1973).

60. See, e.g., Earles v. Union Barge Line Corp., 486 F.2d 1097 (3d Cir. 1973); Watson v. D/S A/S Idaho, 359 F. Supp. 496 (E.D. Pa. 1973); Maryland v. Amerada Hess Corp., 356 F. Supp. 975 (D. Md. 1973); cf. Higginbotham v. Mobil Oil Corp., 357 F. Supp. 1164 (W.D. La. 1973). Contra, Onley v. South Carolina Elec. \& Gas Co., 488 F.2d 758, 759 n.1 (4th Cir. 1973); Rubin v. Power Authority, 356 F. Supp. 1169 (W.D.N.Y. 1973).

61. See, e.g., Crosson v. Vance, 484 F.2d 840 (4th Cir. 1973); cf. Hark v. Antilles Airboats, Inc., 355 F. Supp. 683 (D.V.I. 1973).

62. Despite a finding that an injury occurred on the land or an extension thereof, some courts have pursued the possibility that a maritime nexus would establish admiralty jurisdiction under Executive Jet. See, e.g., Powers v. Bethlehem Steel Corp., 477 F.2d 643 (1st Cir. 1973); Jiles v. Federal Barge Lines, Inc., 365 F. Supp. 1225 (E.D. La. 1973). Others make outright assertions that the Supreme Court has "rejected the 'maritime locality' test in favor of the significant relationship test." Teachy v. United States, 363 F. Supp. 1197, 1198 n.2 (M.D. Fla. 1973); cf. Sandoval v. Victory Carriers, Inc., 354 F. Supp. 996, 997 n.1 (E.D. Pa. 1973); Adams v. Montana Power Co., 354 F. Supp. 1111 (D. Mont. 1973). See generally Kelly v. Smith, 485 F.2d 520 (5th Cir. 1973), noted in 52 Tex. L. Rev. 114 (1973).

63. See Onley v. South Carolina Elec. \& Gas Co., 488 F.2d 758 (4th Cir. 1973); Oppen v. Aetna Ins. Co., 485 F.2d 252 (9th Cir. 1973); Luna v. Star of India, 356 F. Supp. 59 (S.D. Cal. 1973); cf. Higginbotham v. Mobil Oil Corp., 357 F. Supp. 1164 (W.D. La. 1973). See also Moye v. Henderson, No. 73-1871 (8th Cir., filed May 8, 1974). In Moye the district court made a finding of both locality and maritime nexus, but the court of appeal's opinion is ambiguous as to the proper procedural sequence. See id. at 6. 
deny jurisdiction after finding on only one issue, if the case should fail to satisfy that criterion; ${ }^{84}$ under another formulation of the test, the court would be required to find on both issues in an effort to perceive and judge the case as a composite whole. ${ }^{65}$

Further conceptual variations can exist within the finding of a maritime nexus itself: (a) The nexus may hinge upon a critical evaluation of all the characteristics of the action, for example, the nature of the plaintiff, ${ }^{68}$ the nature of the defendant, ${ }^{67}$ the aotivity producing the injuries, and the instrumentality causing the tort. ${ }^{68}$ Under this understanding of the maritime nexus, all aspects of the action must be sufficiently associated with a traditional maritime activity in order for the court to have jurisdiction in admiralty. (b) The nexus may depend upon the existence of one or more specifically emphasized characteristics or relationships in the causal chain which produced the injury. ${ }^{69}$ Thus a fimding that the defendant was engaged in a traditional maritime activity, ${ }^{70}$ or that the instrumentality through which the injury was effectuated was a vessel, ${ }^{71}$ or that the action of the plaintiff was that of a traditional function of a seaman, ${ }^{72}$ would imdependently support the fimding of an adequate maritime nexus for jurisdictional purposes regardless of the non-maritime nature of any other aspects of the action. Here, the only connection or "nexus" required would be causation arising from a specified maritime aspect of the action; the maritime aspects could be defined by concrete rules. For example, a maritime defendant may be defined as either a classical maritime agency such as a vessel or its gear, or something closely analogous to it.

Virtually without exception, each of these possible formulations of the tests for maritime jurisdiction with the related variables

64. See Watson v. D/S A/S Idaho, 359 F. Supp. 496 (E.D. Pa. 1973).

65. See Jiles v. Federal Barge Lines, Inc., 365 F. Supp. 1225 (E.D. La. 1973); Hark v. Antilles Airboats, Inc., 355 F. Supp. 683 (D.V.I. 1973).

66. See Oppen v. Aetna Ins. Co., 485 F.2d 252 (9th Cir. 1973); Powers v. Bethlehem Steel Corp., 477 F.2d 643, 648 (1st Cir.), cert. denied, 414 U.S. 856 (1973); Onley v. South Carolina Elec. \& Gas Co., Civil No. 72-1455 (D.S.C., filed Mar. 5, 1973).

67. See Higginbotham v. Mobil Oil Corp., 357 F. Supp. 1164 (W.D. La. 1973).

68. See Maryland v. Amerada Hess Corp., 356 F. Supp. 975 (D. Md. 1973); Rubin v. Power Authority, 356 F. Supp. 1169 (W.D.N.Y. 1973); cf. Onley v. South Carolina Elec. \& Gas Co., 488 F.2d 758, 760 (4th Cir. 1973).

69. See Chapman v. City of Grosse Pointe Farms, 385 F.2d 962 (6th Cir. 1967); Jiles v. Federal Barge Lines, Inc., 365 F. Supp. 1225 (E.D. La. 1973).

70. See Higginbotham v. Mobil Oil Corp., 357 F. Supp. 1164 (W.D. La. 1973).

71. See Luna v. Star of India, 356 F. Supp. 59 (S.D. Cal. 1973); cf. Rubin v. Power Authority, 356 F. Supp. 1169, 1171 n.1 (W.D.N.Y. 1973).

72. See Ross v. Mobil Oil Corp., 474 F.2d 989 (5th Cir.), cert. denied, 414 U.S. 1012 (1973). 
has found some degree of acceptance in the lower courts since the opinion in Executive Jet was announced. Nevertheless, the results of the decisions themselves are not always objectionable but rather most often represent rational judicial manipulation designed to achieve reasonable results in some difficult borderline cases. The fact that the case law itself can often achieve a degree of rationality in spite of the ambiguities and indeterminancies of the leading opinion indicates the possible existence of an inchoate but more fundamental jurisdictional rule than that which is expressed by Executive Jet.

\section{The Simplest Interpretation}

The first and simplest interpretation of the new rule consists of the minimal holding that the Supreme Court has altered the law of admiralty jurisdiction only to the extent of excluding airplanes crashing into the water from its purview. Under this interpretation, the conventional maritime law remains intact after the Executive Jet decision minus this one minor exclusion. Thus one court has explained:

The Supreme Court did not expand admiralty jurisdiction . . . but Executive Jet further restricted it in regard to aviation tort cases. The Court referred with approval to the locality test, when dealing with ships in traditional maritime situations. ${ }^{73}$

Similarly in Maryland v. Amerada Hess Corp. ${ }^{74}$ the court stated that Executive Jet "did not reject the locality test for jurisdiction in admiralty cases, but merely held it to be insufficient in claims arising from airplane accidents." ${ }^{\prime \prime 5}$ In Amerada Hess, the court asserted admiralty jurisdiction over a case involving a suit by the State of Maryland seeking daunages for an oil spill caused by a rupture of an oil transfer line between the defendant's vessel and co-defendant's plant. However, in explaining its action, the court offered only very general guidelines as to the operation of the jurisdictional rule as it perceived it to be. Confident that the old test had been rejected by the Supreme Court in the case of aircraft accidents because they were "borderline cases," where the application of a strict locality rule produced results which were "absurd" and bore no relationship to the effectuation of definable policies of admiralty law, the court sustained jurisdiction because the case was "not a 'perverse' or 'casuistic borderline situation'

73. Watson v. D/S A/S Idaho, 359 F. Supp. 496, 499 (E.D. Pa. 1973); cf. Victory Carriers, Inc. v. Law, 404 U.S. 202 (1971), where the Court stated, "At least in the absence of explicit congressional authorization we shall not extend the historic boundaries of the maritime law." Id. at 214.

74. 356 F. Supp. 975 (D. Md. 1973).

75. Id. at 976. 
that would require deviation from the application of the traditional locality test."7o

Rather than analytically approaching the reasons why this case was not borderline in terms of some process of evaluating the rational connection between the defendant or his activities and traditional, analogous maritime matters or recognizable substantive admiralty law considerations, the court completely ignored the value of functional definition and announced the fact that this case was neither ambiguous nor "borderline." The court's approacli apparently assumed that "borderline" cases can be readily separated from the "non-borderline ones." The non-borderline cases are those in which imposition of the locality test is not patently "absurd," which is to say that the jurisdiction is appropriate where the results of the apphication of the jurisdictional test do not include within admiralty jurisdiction matters not reasonably associated with maritime law or policy. Thus the court tacitly admitted that the jurisdictional trend evidenced by Executive Jet was based upon certain rational principles, whicl the court simply found unnecessary to define with specificity. The court assumed that locality was rejected in Executive Jet simply because that was a hard case, but that locality sliould continue to govern in the present case which was easy. Judged by almost any standard of a good jurisdictional rule, especially the policy of minimizing litigation concerning jurisdictional principles, a less predictable approach than the "easy/hard" test could hardly be imagined.

\section{Maritime Nexus as Sole Justification}

Other cases effectively hold that the Supreme Court has baldly rejected the locality test and substituted in its place the finding of a maritime nexus as the sole justification for sustaining admiralty jurisdiction. For example, in Jiles v. Federal Barge Lines, Inc., ${ }^{77}$ the court found the absence of a maritime locality when a painter fell and was injured while working on an old steamboat which had been permanently docked and converted into "an extension of the land."78 Despite the indisputable lack of maritime locality, the court nevertheless looked for a connection between the tort and inaritime activities. Only after the court was satisfied that not enough significant elements of admiralty interest existed in the case did it refuse to grant admiralty

76. Id. at 977 .

77. 365 F. Supp. 1225 (E.D. La. 1973).

78. Id. at 1227. 
jurisdiction over the action. ${ }^{79}$ Likewise in Teachy $v$. United States, ${ }^{80}$ the court asserted that Executive Jet had unequivocally "rejected the 'inaritime locality' test in favor of the significant relationship test." Thus, regardless of where a Coast Guard helicopter crashed after it brought persons rescued from a sinking shrimp boat to land, admiralty jurisdiction could not attach if the hehcopter was no longer performing a function traditionally performed by a seaborne vessel. ${ }^{82}$

The case of Sandoval $v$. Victory Carriers, Inc. ${ }^{83}$ is another example of the application of the strict "nexus" approach after Executive Jet. A longshoreman was struck by a piece of lumber which fell from a sling during a loading operation. The fall of the lumber was caused by the fact that the winch operator hoisting the lumber aboard had raised a bundle of lumber too fast, causing it to strike another bundle and become tilted. One of the boards in the bundle dislodged and fell upon the plaintiff-longshoreman. The plaintiff sued the ship owner and operator on the grounds of unseaworthiness and negligence. In denying the defendant's motion for summary judgment, the court concluded that there was sufficient evidence of possible defect in the winch itself, and that failure to remedy the defect may have amounted to negligence on the part of the defendant. ${ }^{84}$ The court was persuaded that the pohicy underlying the Extension of Admiralty Jurisdsiction Act $^{85}$ removing the locality barrier to asserting admiralty jurisdiction over shore-damage caused by vessels, coupled with the fact that the pleadings alleged unseaworthiness of the vessel qua negligence, ${ }^{80}$ was sufficient to uphold jurisdiction. Earlier cases had so held. ${ }^{87}$ Given this policy basis and this alleged maritime question of fact, the court explained:

79. Id. at 1228-29.

80. 363 F. Supp. 1197 (M.D. Fla. 1973).

81. Id. at 1198 n.2.

82. Id. at 1199. The helicopter had completed the "performance of a function traditionally performed by waterborne vessels (i.e., the performance of search and rescue operations)" when it landed to refuel at Key West, Florida. Id. The decedent was killed on the second leg of the trip-Key West to St. Petersburg.

83. 354 F. Supp. 996 (E.D. Pa. 1973).

84. Id. at 1000 .

85. 46 U.S.C. $\$ 740$ (1970).

86. A recent amendment to the Longshoremen's and Harbor Workers' Compensation Act has affectcd the substantive basis for actions by longshoremen against vessels, as well as the traditional "remedy-over" by vessel owners against stevedores. See 33 U.S.C. \$ 905(b) (Supp. II, 1972), amending 33 U.S.C. \$ 905 (1970). For the legislative history of amendment to the Longshoremen's and Harbor Workers' Compensation Act, see 3 U.S. Code Cong. \& AD. News 4701-05 (1972).

87. See, e.g., Gutierrez v. Waterman S.S. Corp., 373 U.S. 206 (1963). 
[Executive Jet] did not diminish the admiralty jurisdiction in the case .... even though the relationship of the wrong to traditional maritime activity test were to be used instead of the Extension Act. ${ }^{88}$

Hence, a simple finding of an identifiable maritime policy regarding the alleged responsibility of this defendant was sufficient to find a maritime nexus and admiralty jurisdiction with or without the precedent of Executive Jet. Consequently, no finding of locality was inade necessary in the opinion of the court, a decision which appears to be eminently reasonable to these authors.

Although the form of these decisions is sometimes confusing, other courts lave used similar processes to resolve jurisdictional questions. In Powers $v$. Bethlehem Steel Corp. ${ }^{80}$ the plaintiff was engaged in repair operations on a pier and sustained serious eye injuries caused by an exploding light bulb as he was standing on a raft or float under the pier on which he worked. Plaintiff collected for his injuries under the Longshoremen's and Harbor Worker's Compensation Act and filed separate actions against his employer, who owned the raft, and Bethlehem Steel Company, which owned the pier and which had contracted with plaintiff's employer. The action against plaintiff's employer was based upon the Jones Act, as well as upon maintenance and cure under general maritime law, and the action against Bethlehein Steel was based upon negligence which the plaintiff claimed should be determined under general maritime law. The action against the einployer was founded upon alleged admiralty jurisdiction, and federal jurisdiction over Bethlehem rested upon diversity of citizenship; however, the finding of admiralty jurisdiction would also have determined the apphicable law in the diversity action. The court discussed the substantive basis for a Jones Act claim, which required "affiliation with a 'vessel' -either as a crew member or as one injured aboard doing seaman's work." 90 After discussion of the physical characteristics and operation of the raft and its possible similarity to a conventional vessel used in actual navigation, the court was able to exclude the raft from that defimition. ${ }^{01}$ Thus the claim against plaintiff's einployer had to fall, since

88. 354 F. Supp. at 997 n.1.

89. 477 F.2d 643 (1st Cir.), cert. denied, 414 U.S. 856 (1973).

90. Id. at 646.

91. "The raft's only movement was from the pier front to the piles underneath or from one row of piles to another. Even when so moving it was normally attached by at least one line to the pier." Id. at 645 (footnote omitted). The raft itself was made "of 12 by 12 timbers, bonded together," and the repair equipment would be lowered from the pier onto its surface. Further, the purpose of the raft in no way resembled that of conventional vessels: "The purpose and business of the present raft was not the transportation of passengers, cargo, or equipment from place to place 
the substantive claims raised by the plaintiff required the cause of the injury to be related to a "vessel."

Addressing the claim against Behlehem, which was rejected, the court articulated its understanding of the jurisdictional rule in Executive Jet, which had to be satisfied in order for maritime law to apply:

Maritime law applies only where the wrong occurring on or over navigable waters "bear[s] a significant relationship to traditional maritime activity." . . . It would be incongruous to hold that the required relationship existed here, in the face of our conclusion that the raft was not a vessel, but, being a floating work platform, was, in effect, an extension of the pier, itself an extension of the land. ${ }^{92}$

It might appear that the court was constrained to deny jurisdiction on two grounds: under the locality test, the injury occurred on an extension of the land, and under the maritime nexus test, the injury was not connected with a significant relationship to traditional inaritime activity. However, the rationale for determining the character of the locality in effect coincided with the rationale for determining maritime relationship, since both rested upon the finding that the repair raft was not a vessel because it was almost always attached to the pier. The locality and maritime nexus tests were thus highly interrelated, if not synonymous. Consequently, in its analysis of the question of admiralty jurisdiction, the court addressed itself fundamentally to an empirical, factual evaluation of the propriety of a inaritime designation of the function which the raft was performing at the time the accident occurred. In the view of the court the locality test itself is reduced to a test of the maritime nexus or nature of the locality, which effectively annihilates the old locality rule in favor of a strict maritime nexus test. Furthermore, having found that the raft was effectively an extension of the land, the court nevertheless found it necessary to consider the nature of the plaintiff's occupation and of the circumstances of the accident in order to determine whether a maritime connection existed which might entitle the plaintiff to invoke admiralty jurisdiction in the case. Accordingly, when the court summarized the import of Executive Jet as reserving admiralty law for cases arising out of controversies concerning vessels which "ply the waterways of the world,"93 the court must be understood to be discountimg the locality determination in favor of a strict maritime function test based upon the finding of an

across navigable waters. It was tied to the pier or its pilings virtually all the time." It was thus "indistinguishable from a permanent floating dock." Id. at 647.

92. Id. at 648 .

93. Id. 
admiralty nexus between the injury incurred and the action out of which the complaint arose.

\section{The "Locality Plus" Test}

Further cases clearly read Executive Jet as creating an equally balanced dual test of "locality plus" for admiralty jurisdiction. In $O P$ pen v. Aetna Insurance Co., ${ }^{94}$ one of the cases arising out of the 1969 Santa Barbara oil spill, the Ninth Circuit Court of Appeals articulated the requirements of the rule as follows: "[L]ocality alone is not sufficient. We must also decide whether the wrong bears 'a significant relationship to traditional maritime activity." "95 The court found that the right which the plaintiff sought to vimdicate was of a maritime nature and thus, despite the probable non-maritime nature of the defendant's activity in causing the oil danage, admiralty law controlled the substantive disposition of the case. ${ }^{96}$

Also following a "locality plus" interpretation of Executive Jet, but this time focusing on the maritime character of the defendant's activities, is a passage in Higginbotham v. Mobil Oil Corp. ${ }^{97}$ Here plaintiffs' decedents were a helicopter pilot and several workers on an offshore oil rig owned by one of the defendants, Mobil Oil. The decedents were killed when the helicopter carrying thein from the rig crashed offshore. Both Mobil and the manufacturer of the helicopter were sued. The court demed rehef against the manufacturer due to the absence of any evidence indicating a design or manufacturing defect. It permitted relief, however, against Mobil, the einployer and operator of the aircraft, under the doctrine of res ipsa loquitur. In granting admiralty jurisdiction, the court found a maritime nexus by analogizing the defendant's conduct and the circumstances of the accident to features associated with conventional maritime enterprise:

The accident occurred on high seas over the outer Continental Shelf in the Gulf of Mexico far outside the boundaries of the State of Louisiana, and thus satisfies the traditional locality test of jurisdiction .... The fated helicopter was owned and operated by Mobil in conjunction with its extensive offshore activities, and, at the time of the fatal accident, was performing the ordinary functions of a crewboat. Unquestionably it was engaged in maritime activity and was not oper-

94. 485 F.2d 252 (9th Cir. 1973).

95. Id. at 256. Here it was the plaintiff who was seeking to avoid the substantive law of admiralty in order to enforce a state claim of nuisance against the defendants.

96. Id. at 257.

97. 357 F. Supp. 1164 (W.D. La. 1973). See also Teachy v. United States, 363 F. Supp. 1197 (M.D. Fla. 1973), discussed in notes 80-82 supra and accompanying text. 
ating as a "land-based aircraft between points within the continental United States." 98

Other cases have evidenced a preoccupation with the maritime character of the defendant or his activities, classifying these either according to traditional maritime definitions, or by analogy to traditional maritime matters, and have thus tended to view even locality with some flexibility. For example, in Luna $v$. Star of India, ${ }^{99}$ the court applied the new jurisdictional rule to a case involving personal injuries sustained aboard an antique sailing vessel, the Star of India, which was permanently moored to a pier in San Diego and used as a maritime museum. The plaintiff was a visitor to the Star and asserted a claim in admiralty against the owners and operators of the vessel. Unlike the court in Jiles v. Federal Barge Lines, Inc., ${ }^{100}$ this court found no initial difficulty with the locality, since "the Star was afloat on navigable waters at the time in question."101 Citing Chapman, the court, however, acknowledged that Executive Jet should be interpreted to mean that the jurisdictional rule is now a "locality plus" test. Although the plaintiff argued that the decision in Executive Jet did not foreclose the continued apphication of a strict locality rule in non-aviation cases, the court was "greatly impressed by the soundness of reasoning to be found in the arguments of the critics of the 'strict locality' rule,"102 and proceeded to imquire whether a maritime nexus existed within the facts of the case. ${ }^{103}$ In the face of the defendants' argument that the vessel was permanently affixed to the adjoining pier, abrogating its ability to conduct any practical navigation or function ordinarily performed by a vessel, ${ }^{104}$ the court acknowledged a mari-

98. 357 F. Supp. at 1167 (emphasis added). See id. at 1174.

99. 356 F. Supp. 59 (S.D. Cal. 1973).

100. See notes 77-79 supra and accompanying text.

101. 356 F. Supp. at 61.

102. Id. at 62 .

103. Id. at 63 .

104. The defendant introduced findings by the U.S. Coast Guard made pursuant to licensing and inspection practices which, as a basis for relieving the Star of these requirements, stated that she was "substantially a land structure" since it is established that the moorings cannot be inadvertently or accidently [sic] cast off, that it would not likely break its moorings, or that it could not be moved without special effort, such as with the use of tools." Id. The Star also had electrical and water connections running from the shore.

Because of its emphasis on the need for a floating structure to be engaged in actual navigation and to have a function that "requires exposure to the hazards of the sea," it seems likely the Powers court would have agreed with the defendant and denied admiralty jurisdiction in this case. 477 F.2d at 647. See notes 89-93 supra and accoinpanying text. 
time nexus in an interesting and colorful analysis of the basic maritime character of the Star as a vessel. The court stated that

it can fairly be said that visitors to the Star of India do not pay admission merely to view the memorabilia collected below in a few glass cases, but they come aboard to enjoy the unique experience of trodding the decks and inspecting the lofty rigging of this old sea voyager. . . .

... Were she presently slipped from her moorings, whether deliberately or by chance, she would undoubtedly be capable of engaging in maritime transportation, if only as a towed craft. . . . We are reminded of the endeavors of men who dared to navigate oceans in far less seaworthy craft. ${ }^{105}$

But why the pernanence of the mooring, rendering the Star an extension of the land, did not preclude the finding of maritime locality was not adequately explained by the court. Nevertheless, the court's conclusive determination of locality at the outset imdicated that it construed the test as requiring a separate finding on both locality and maritime nexus.

Moreover, Luna v. Star of India is not the only decision which has held that the designation of the presence of a "vessel" in the case controls the finding of a maritime nexus. In Hark v. Antilles Airboats, Inc. ${ }^{106}$ it was noted that if location were still the sole test, a seaplane takeoff accident occurring after the plane is airborne could be distinguished froin an admiralty suit on the grounds that a seaplane, once in the air, is not a vessel for purposes of substantive admiralty law. But under the nexus rule as propounded by the Supreme Court in Executive Jet, the court regarded itself bound to consider whether the plane was serving the role of a vessel at the time of the accident,

105. 356 F. Supp. at 66 .

106. 355 F. Supp. 683 (D.V.I. 1973). In order to avoid the expiration of the statute of limitations on his common law claim, the plaintiff asserted admiralty jurisdiction over a claim for personal injuries arising from the crash of a seaplane on which the plaintiff was a passenger. The seaplane crashed into navigable waters after attempting to take off. The plane had reached an altitude of about 200 feet but had not attained "minimum control speed." After analyzing previous cases which applied admiralty jurisdiction to seaplanes that had accidents while still on the water, and comparing the present case with those involving the fall of land based planes into navigable waters, the court concluded that the physical characteristics and practical considerations of seaplane flights, at least those over international waters or between territorial islands, made such flights sufficiently maritime in order to meet the standards of the Executive Jet test. Also, the court suggested that "[t]he 'marine' character of the venture also persists for some distance after the plane has left the water and is no longer under formal navigational rules." Id. at 686. The court interpreted Executive Jet to require a test beyond locality, stating that the Supreme Court meant that "[i]n addition to a maritime location, the tort must also have 'a significant relationship to traditional maritime activity." "Id. at 685-86. 
thereby making the designation "vessel" itself of jurisdictional importance. ${ }^{107}$ Likewise, Rubin v. Power Authority ${ }^{108}$ implies in dicta that even if a maritime nexus is lacking, the involvement of a vessel in causing the injury may be enough to sustain admiralty jurisdiction even under Executive Jet. ${ }^{109}$ But to the contrary, other cases have firmly held that the presence or absence of a vessel is now wholly irrelevant to the jurisdicitional determination, ${ }^{110}$ especially if the plaintiff himself is not engaged in soine traditional activity of a seaman when his in-

107. Id. at $686 \mathrm{n} .2$. The court discussed the peculiarly maritime problems of takeoff and landing encountered by seaplanes, including the need to abide by maritime rules of the road in cases of eugiue failure, and the possibility that take-off or landing waters might be "fraught with flotsam or ligan or just plain pollution and erratic boaters and snorkelers-all posing maritime dangers, not at all common to land based planes." Id. at 686. Quoting Mr. Justice Stewart's comment in Executive Jet that international flights performed "a function traditionally performed by waterborne vessels," $i d$. at 687 , and citing the "especial conveniences" of an admiralty forum in cases involving activities not confined to a single nation, the court concluded that "the oar should be placed on the bench, (an English tradition indicating that the judge is hearing an admiralty case)" and so it was. Id. at 684, 686. Thus it appears that the court ascribed to the "locality plus" interpretation of Executive Jet, coupled with a defendant-oriented analogy between the defendant's activities and maritime activities.

108. 356 F. Supp. 1169 (W.D.N.Y. 1973), where the representatives of divers drowned in the water intakes of a generating plant owned by the defeudant attempted to assert admiralty jurisdiction. Citing language from Executive Jet, the court concluded that "satisfaction of the locality test is insufficient to sustain admiralty jurisdiction, and that it must also be shown that the tortious acts alleged in the complaints bear "a significant relationship to traditional maritime activity." Id. at 1171 . The court then analyzed the nature of defendant's activities in terms of the alleged wrongdoing - the failure to erect barriers or warning signs or markers to prevent users of the waters from being drawn into the intakes of the geuerating plant-and concluded that these activities did not correlate with "maritime service, navigation or commerce," which were historically the basis for asserting admiralty jurisdiction, and thus denied jurisdiction.

109. Id. at 1171 n.1. Compare Judge Benedict's "celebrated doubt" as to whether adıniralty jurisdiction did not essentially depend upon some "relation of the parties to a ship or vessel." E. BENEDICT, THe AMERICAN ADMIRALTY 173 (1850), cited in Executive Jet Aviatiou, Inc. v. City of Cleveland, 409 U.S. 249, 257 (1972). See also Hough, Admiralty Jurisdiction-of Late Years, 37 HARV. L. REv. 529, 531 (1924).

110. See Earles v. Union Barge Liue Corp., 486 F.2d 1097 (3d Cir. 1973). See also Crosson v. Vance, 484 F.2d 840 (4th Cir. 1973), wherein the Fourth Circuit Court of Appeals denied admiralty jurisdiction in a suit brought by a water skier against the operator of the towing motor boat. Though the court noted earlier cases in which pleasure boat activity was regarded as properly within admiralty jurisdiction, the court felt that the reference to King v. Testerman, 214 F. Supp. 335 (E.D. Tenn. 1963), by the Supreme Court in Executive Jet, 409 U.S. at 256 n.2, as an example of the potentially absurd results of the locality test, was an explicit rejection of the contention that these activities could supply the necessary "maritime relationship" requirement of the new jurisdictional rule. Id. at 842; cf. Moye v. Henderson, No. 731871 (8th Cir. filed May 8, 1974). See generally Adams v. Montana Power Co., 354 F. Supp. 1111 (D. Mont. 1973); 33 Mrss. L.J. 1013 (1973). 
juries are sustained. ${ }^{111}$

\section{Additional Variables Within the "Locality Plus" Rule}

One other case following the "locality plus" formula, the recent decision in Onley v. South Carolina Electric \& Gas Co., ${ }^{112}$ further illustrates the futility of jurisdictional litigation in an area in which the courts liave failed to give a clear procedural definition to elements of the jurisdictional rule which they attempt to apply. The district court rendered one of the most unstructured decisions dealing with the new jurisdictional rule among the post-Executive Jet cases. Moreover, the court of appeals, though clear in the reasons for its decision on the jurisdictional point, also clearly evinced the practical aunbiguity of the jurisdictional rule of Executive Jet. The libel in this case arose when the plaintiff was imjured while diving from a dock on Lake Murray, striking a submerged boat ramp. The plaintiff sued the South Carolina Electric and Gas Company, which owned and controlled the lake up to the high water or contour mark and used the waters for the generation of electricity. The plaintiff asserted admiralty jurisdiction, alleging that the defendant's control of the level of an entire body of navigable water entailed inaritime activities. The power company answered that the tort did not occur on navigable waters, did not have a maritime locality, and did not have the required maritime nexus. In the argument of the case, the parties focused upon the maritime nexus requirement, and little was said regarding the assumed navigability at the situs of the tort. ${ }^{113}$ The court, however, held that jurisdiction was absent due to a categorical exclusion of the plaintiff's activityswimming-from the domain of maritime concern. Replying to the plaintiff's argument regarding the maritime character of the defendant's activity, the court asserted that "they make light-the Supreme Court does-of causes such as swimming cases. They just say that swimming cases have got nothing to do with maritime activities."11.4

111. See Ross v. Mobil Oil Corp., 474 F.2d 989 (5th Cir.), cert. denied, 414 U.S. 1012 (1973). See note 110 supra.

112. 488 F.2d 758 (4th Cir. 1973).

113. See Record at 3, Onley v. South Carolina Elec. \& Gas. Co., Civil No. 72-1455 (D.S.C., filed Mar. 5, 1973). The District Judge at the outset of the argument asserted that the principal and controlling question was the presence of a maritime nexus, and later resolved the case on this point.

114 Record at 15, Onley v. South Carolina Elec. \& Gas. Co., Civil No. 72-1455 (D.S.C., filed Mar. 5, 1973). The court was evidently referring to the Supreme Court's citation of the American Law Institute's Study of the Division of Jnrisdiction Between State and Federal Courts in the Executive Jet decision. See 409 U.S. 249, 257-58 (1972). The district judge in Onley repeatedly asserted the categorical lack of 
In a particularly unperceptive opinion, the court on one hand disposed of the case on the ground that swimming could never provide a maritime nexus, while on the other hand it said that jurisdiction was lacking because it could find "no substantial relationship between the tort complained of and traditional maritime activity."115 Thus, locality was virtually ignored, and the opinion provides no guidelines as to what procedure to employ in determining the content of a maritime nexus.

On appeal to the Court of Appeals for the Fourth Circuit, the locality issue, along with the maritime nexus, was argued. ${ }^{116}$ The court of appeals discounted the role of locality under the new test, and proceeded directly to the maritime nexus requirement, stating that "[w]hatever the role of the locality test in determining admiralty jurisdiction after Executive Jet Aviation, the Supreme Court clearly restricted such jurisdiction by adding the requirement of a nexus to traditional maritime aotivity."117 The case was found to be lacking on the latter poimt. The approach of the court of appeals in determining the maritime nexus, however, differed froin that used by the district court. Distinguishing cases cited by the plaintiff in an effort to establish the maritime character of the defendant's activity, the Court found that the activity of the defendant was in fact not maritime. ${ }^{118}$ The count of appeals stated:

We hold that appellee's control of the water level of a lake for the purpose of generating electricity, which results in a diving accident, does not bear a sufficiently significant relationship to traditional maritime activity to create federal admiralty jurisdiction. While the control of the water level of a navigable waterway may, in some cases, have an intimate relationship with maritime activities, there is no such maritime connection where a diving accident is the only consequence. ${ }^{119}$

connection between swimming and any maritime concern: "Now a swimming accident, however it might happen, has got nothing to do with any business conducted on navigable waters or business of the sea. There is no connection between maritime activities, that I can see, and a swimming accident . . . ." Record, supra, at 22. "[Y]ou have got to have some nexus with what you and I and the courts have establisked as a maritime activity, and swimming itself is not a maritime activity." Id. at 23.

115. Onley v. South Carolina Elec. \& Gas. Co., Civil No. $72-1455$ at 3 (D.S.C., filed Mar. 5, 1973).

116. Brief of Appellee at 10, Onley v. South Carolina Elec. \& Gas. Co., 488 F.2d 758 (1973).

117. 488 F.2d at 759 .

118. Id. at 760. Rubin v. Power Authority, 356 F. Supp. 1169 (W.D.N.Y. 1973), discussed in note 108 supra, Adams v. Montana Power Co., 354 F. Supp. 111 (D. Mont. 1973), and McCall v. Susquehanna Elec. Co., 278 F. Supp. 209 (D. Md. 1968), were the cases principally discussed by the court of appeals in Onley.

119. 488 F.2d at 760 . 
Thus the district court and the court of appeals were able to reach the same result by different jurisdictional approaches. The district court seized upon a superficially plausible rationale for denying jurisdiction, though it declined to think through the variations in meaning of the Executive Jet opinion and the task of giving form to the rule. It thus adopted a "plaintiff's exclusionary rule" by categorizing the plaintiff's activity as per se "un-maritime." On the other hand, the court of appeals employed a defendant-oriented test and analogized this case to other cases involving an analysis of the relationship between the activities of the defendant and maritime matters. This, plus the indeterminancy in both the district court's and the court of appeals' opinions as to the role of locality clearly illustrates the ambiguity inherent in the rule as formulated in Executive Jet.

To reiterate, the formulation of a jurisdictional rule in the Onley decisions-such as it is formulated-is clearly insufficient. If the nature of these holdings and the language of the courts in arguinent is indicative of any formal rendition of a rule, it amounts to a process of denominating a certain class of activities which cannot suppont admiralty jurisdiction, no matter what the cause of the injury or nature of the defendant might be. But the difficulty inherent in any such denomination is readily exposed. If the plaintiff in Luna v. Star of India, for example, had been a swimmer rather than a visitor to the vessel, or if a swimmer had been run down by a vessel, the Onley test, taken literally from the district court, would foreclose the consideration of compelling maritime concerns or policies related to the defendant. It would, as applied by the district court, be as rigid and susceptible to irrational results as the pure locality test. If the rule is thouglit to be a inandate for the denial of jurisdiction anytime a single significant element of the litigation is found by the court to be "non-maritime," then the failure of the court to enunciate the criteria for detecting the characteristics of significant "maritime" eleunents is no better than an abandonment of the problem to ad hoc determinations, which is to have no rule at all. Only slightly better is the approach used by the court of appeals. However, if that rule's content were to be more extensively articulated and the significance of locality resolved, it could come close to fulfilling the rational objectives of $E x$ ecutive Jet and to presenting an efficient, formal jurisdictional test.

\section{Formulating a NEW JURISDictional RULE}

In order to delineate the formal content of the current law of admiralty jurisdiction, it is necessary to define the functional aspects 
of the Executive Jet decision and its progeny, and to place this landmark decision in the broader patterns of recent jurisdictional history. From the results of the foregoing analysis of the lower courts' attempts to apply the new rule promulgated by Executive Jet, it is apparent that the rule of Executive Jet is by no means uniformly understood or applied. ${ }^{120}$ The difficulty, we hope to prove, lies not in the direction in which the Court has generally moved, but in its failure to sever all formal ties with the old locality criterion and to reduce the rule to a formula which can be implemented with a minimum of delay and deliberation. As the rule is currently employed, however, the efficiency of judicial resources and the predictability of the resultant decisions are probably both lower under Executive Jet than they were under the old (sometimes irrational) locality rule. It is our contention that efficiency and predictability need not be sacrificed in order to achieve rational results in admiralty jurisdictions. The old rules were not bad because they had form, but because of the substantive results which the form came to produce. The new rule will not necessarily be enhanced by a lack of form.

We posit at the outset that it is desirable, if not necessary, for the elements of a jurisdictional rule to have some definite form and to be applied in some clearly ordered manner. The obvious divergence in the various interpretations given to the rule by different courts, even when applied to the same facts at different stages of a single suit's litigation, e.g., the Onley litigation ${ }^{121}$ or Executive Jet itself, ${ }^{122}$ reveal that without assuming a more defimitive form the current rule will never achieve a satisfactory degree of efficiency. The contradictory results reached in the Jiles and Luna cases, ${ }^{123}$ which presented substantially identical fact situations, indicate further the sheer unpredictability of the rule as it is now constituted.

The problems involved in creating a satisfactory jurisdictional rule are, however, not peculiar to the area of admiralty jurisdiction in tort litigation. Many of the same difficulties which the courts of admiralty are now experiencing were also encountered in the wake of International Shoe Co. v. Washington, ${ }^{124}$ which analogously imtroduced juris-

120. See notes 59-72 supra and accompanying text.

121. See notes $112-19$ supra and accompanying text.

122. See notes 40-57 supra and accompanying text.

123. See notes 77-79, 99-105 supra and accompanying text.

124. 326 U.S. 310 (1945). Our criticism of Executive Jet and our formulation of a test for admiralty jurisdiction in tort have been heavily influenced by the Supreme Court's evolution of a test for state court jurisdiction from Pennoyer v. Neff, 95 U.S. 714 (1877) to Hanson v. Denckla, 357 U.S. 235 (1958). The similarities in the Su- 
dictional reforms into state court jurisdiction on a conceptual rather than practical level. The process specified an evaluation particularly of the interests and conditions of the parties in any given case, ${ }^{125}$ with a primary concern for avoiding unfairness and inconvenience for the defendant, ${ }^{126}$ in an effort to achieve intuitively reasonable results. The classic formulae from the older jurisdictional rules, such as in rem and in personam, were relegated to a lesser position of descriptive labels ${ }^{127}$ rather than the essence of the rule itself. ${ }^{128}$ Yet in the midst of these

preme Court's past approach to jurisdictional problems in the areas of admiralty and state court jurisdiction are striking. Like the locality rule in tort, state court jurisdiction under Pennoyer was thought to depend upon natural "power" limitations that restrained the states' ability to adjudicate controversies between their own citizens and nonresidents. See Pennoyer v. Neff, 95 U.S. 714, 722-23, 733-34 (1877). In fact, no such physical barriers to the exercise of state authority exist in our system. Rather, the only limiting principles imposed upon the states are contained in the Constitution of the United States, and the Supreme Court is the ultimate expositor of the provisions of that document. See Kurland, The Supreme Court, The Due Process Clause and the In Personam Jurisdiction of State Courts, 25 U. CH. L. Rev. 569, 585 (1958). The primary contribution of International Shoe was the Court's recognition of its responsibihty for the articulation of rational jurisdictional principles to govern state court jurisdiction over nonresidents. As in its approach to admiralty jurisdiction over tort in Executive Jet, the Court has apparently not yet discarded all vestiges of the old physical power tests of state court jurisdiction. See Hanson v. Denckla, 357 U.S. 235 (1958). However, the "minimum contacts" test of International Shoe had added clar. ity to the area of state court jurisdiction and supplied a more accurate reflection, analytically speaking, of state court authority over nonresidents in our federal system. It is urged that Executive Jet represents the initial step in a similar evolution of a rational test of admiralty jurisdiction over tort. For a more complete description of the developments in state court jurisdiction, see e.g., Ehrenzweig, The Transient Rule of Personal Jurisdiction: The Power Myth and Forum Conveniens, 65 YALE L.J. 289 (1956); Hazard, A General Theory of State-Court Jurisdiction, 1965 SUPREMe CoURT Rev. 241; Kurland, supra; von Mehren \& Trautman, Jurisdiction to Adjudicate: A Suggested Analysis, 79 HARv. L. Rev. 1121 (1966); Note, Developments in the Law-State Court Jurisdiction, 73 HARV. L. Rev. 909 (1960).

125. See Hess v. Palowski, 274 U.S. 352 (1927) (the dofendant, a nonresident, caused injuries within the state by the negligent operation of his automobile); Schutt v. Commercial Travelers Mut. Accident Ass'n of America, 229 F.2d 158 (2d Cir.), cert. denied, 351 U.S. 940 (1956). Here the contact with the forun amounted to being the insurer of a resident of the forum who had moved to the forum state after taking out the policy of insurance. The passive fiduciary relationship of a nonresident defendant with parties within the forum state was considered sufficient to support a limited type of judgment against the nonresident in Atkinson v. Superior Court, 49 Cal. 2d 338, 316 P.2d 960 (1957).

126. See Note, supra note 124 , at 924 .

127. Hanson v. Denckla, 357 U.S. 235 (1958), where the Supreme Court states: "While the in rem and in personam classifications do not exhaust all the situations that give rise to jurisdiction, they are adequate to describe the affiliating circumstances suggested here, and accordingly serve as a useful means of approach to this case." Id. at 246 (footnote omitted).

128. However, at times the substance as well as the forn of the old rules still seems to be resorted to in the disposition of difficult cases, both in the Supreme Court and 
striking developments in rethinking and redefining the old rules, there remained the underlying distinctions between state and federal law essential to the construction of an efficient, flexible federal system of government. ${ }^{129}$

In much the same inanner, the Supreme Court has issued a new jurisdictional rule for admiralty jurisdiction. Executive Jet, while einbracing the concept of a rationally based rule for the power of the admiralty courts, has likewise declined to address itself to the probleins inherent in the number of various practical applications which the rule can assume. ${ }^{130}$ Although the precipitating impetus for the imtroduction of the new rule arose out of the inodern problems unique to aviation accident litigation, the Executive Jet decision reflects the need for similar conceptual adjustment in the rule throughout the area of maritime jurisdiction. ${ }^{131}$ The new rule is certainly intended to control cases arising out of the modern problems of aquatic recreation, oil

in lower federal courts. See Hanson v. Denckla, 357 U.S. 235, 250 (1958), for a rather literal application of the in rem concept; Minichiello v. Rosenberg, 410 F.2d 106 (2d Cir.), cert. denied, 396 U.S. 849 (1969), where the court, in upholding jurisdiction on a rehearing en banc, relied heavily on the case of Harris v. Balk, 198 U.S. 215 (1905).

129. In retrospect, it seems apparent that the restrictive view of state authority over nonresidents represented by Pennoyer would have, if left unmitigated, seriously impaired the regulatory power of the states in times of expanding corporate enterprise. Even the fictional theories of "consent" and "presence," which were developed in mitigation of the strict rule of Pennoyer, were doctrinally inadequate in terms of the view they represented of the federal system. Their deficiencies have been articulately described by Professor Phillip Kurland:

The real difficulty underlying these attempts to work out a rationale for personal jurisdiction lay in the fact that the doctrines were borrowed froin laws relating to wholly independent sovereignties which were not relevant to jurisdictions joined in a federation. The basic premise for such decisions was "that a judgment . . . . is necessarily something to be enforced and that a state which is physically impotent to enforce its judgineuts should be treated as legally incompetent to adjudicate ...." But with the Full Faith and Credit Clause as an overriding principle, such a premise only puts the question; it does uot answer it. The real question becomes not whether a state itself could enforce a judgment, but rather under what circumstances the national power should be used to assist the extra-territorial enforcement of a state's judicial decrees. Kurland, supra note 124, at 585 (footnotes omitted).

The true contribution of International Shoe to the concept of federalism lay in its recognition that the national power should stand ready to assist the states in asserting authority over nouresidents in a broader variety of cases. The states have responded to this invitatiou to copartnership by the enactment of broader-based loug arm statutes. See, e.g., ILL. ANn. Star. ch. 110, \& 17 (Smith-Hurd 1968). Thus the total picture of the interaction between state and federal law after International Shoe portrays a more efficient and flexible federal system than existed under Pennoyer.

130. See text accompanying notes 60-65 supra.

131. See Nations v. Morris, 483 F.2d 577, 585 n.27 (5th Cir.), cert. denied, 414 U.S. 1071 (1973). The Supreme Court clearly did not limit the scope of its discussion to either traditional maritime or aviation torts. See 409 U.S. at 256 n.6. 
transportation, seaplane accidents, and so forth. ${ }^{132}$ Whereas no particular inconvenience of venue to the defendant is a consideration in choosing an admiralty forum, the inconveniences and increased burdens of following a specialized body of substantive law and the lack of a general statute of limitations should be of relevance to the consideration of admiralty jurisdiction, if the defendant himself is not a person whoin the substantive law of admiralty was intended to reach. ${ }^{133}$ At the same time, the court has also reasserted its concern for unaintaining a proper balance between state and federal law in the admiralty area, ${ }^{134}$ and this factor should also enter into the assertion of jurisdiction by a court of admiralty.

Similarly, the role of locality in admiralty has changed from that of a designation which was once reasonable, in that in former times it likely signaled "a congeries of other significant affiliations with the forum that would, upon proper analysis, ground jurisdiction," ${ }^{136}$ to a less significant portion of a broader-scoped jurisdictional test, a portion which, like the designation "in rem," really only served as a label in the first place. As a inere label, therefore, the term has properly lost its jurisdictional significance. ${ }^{136}$ The situations evidencing the breakdown and inefficiency of the locality rule were ones in which the mechanical application of the rule brought cases into the court which, on a rational basis, would be excluded, ${ }^{137}$ and excluded cases which were logically identical to those which the locality rule would include. ${ }^{138}$ The locality rule necessarily reaches this absurd result because it operates inflexibly. Yet, strict rehance on a maritime locality test to deny jurisdiotion is not entirely rational, since the locality concept inay be in fact a derivative concept of the nuaritime relationship. ${ }^{138}$ Moreover, the locality test has been subject to numerous in-

132. See, e.g., Crosson v. Vance, 484 F.2d 840 (4th Cir. 1973); Adams v. Montana Power Co., 354 F. Supp. 1111 (D. Mont. 1973).

133. See Onley v. South Carolina Elec. \& Gas Co., 488 F.2d 758 (4th Cir. 1973).

134. See Askew v. American Waterways Operators, Inc., 411 U.S. 325 (1973).

135. von Mehren \& Trautman, supra note 124 , at 1138.

136. In order to be an effective jurisdictional label, a term of art must entail certain jurisdictional results by itself. If the finding of "in rem," "in personam" or "maritime locality" is not of ultimate jurisdictional consequence, then some further, more basic concept has im effect preempted the jurisdictional field, leaving the old label itself of little significance.

137. For example, the "mjured swimmer" cases cited in Executive Jet, 409 U.S. at 256 n.5.

138. See the Supreme Court's discussion of T. Smith \& Son v. Taylor and Minnie v. Port Huron Terminal Co., 409 U.S. at 255.

139. See Adams v. Montana Power Co., 354 F. Supp. 1111 (D. Mont. 1973). The court explains that a locality is not designated as a maritime locality unless a traditional maritime activity is conducted upon the waters at that locality. Id. at 1112. 
roads explicitly based on maritime relationships or policies, and experience with physical or quantitative tests such as locality or presence has demonstrated that their utility and certainty may well be more apparent than real. ${ }^{140}$ Therefore, the movement toward an analytical jurisdictional rule, as was the case in International Shoe, should turn away from the use of rigid and other irrational conclusory labels.

Thus it is submitted that locality should have no place in the new jurisdictional rule. It makes no more sense to exclude from admiralty jurisdiction on the basis of locality a case which should be within it (in that it satisfies maritme relationship requirements) than to include a case which should be excluded. Yet locality operates equally as a mechanical inclusionary and exclusionary rule. Nor can it be countered that congressional action is required to expunge the locality test from the rule of admiralty jurisdiction, since the basic jurisdictional grant is broad enough to permit several definitions of "arising in admiralty or maritime" connections. ${ }^{141}$ Hence, any formulation of the jurisdictional test which involves locality as a formal part of the rule poses the risk of defeating the principal objective of the new test:

Thus, the finding of a maritime locality is dependent upon a prior finding that the locality is used for maritime activities, and hence the locality finding is derived from that prior determination. For a similar result in finding the presence of a "vessel," see Luna v. Star of India, 356 F. Supp. 59 (S.D. Cal. 1973).

140. The responsibilities of various parties prescribed by substantive maritime law render locality irrelevant to jurisdictional decisions in areas covered by those substantive principles. For example, consider the Longshoremen's and Harbor Workers' Act provisions extending employer liability to injured employees shoreward. 33 U.S.C. $\$ \S$ 901 et seq. (Supp. II, 1972). Consider the liability of the vessel owner for shoreside mjuries to seamen under the Jones Act, 46 U.S.C. $\$ 688$ (1970). Likewise consider the liability for shoreside injuries caused by a vessel under the general maritime law doctrine of unseaworthiness. Consider Gutierrez v. Waterman S.S. Corp., 373 U.S. 206 (1963), and the congressional abrogation of the locality rule in cases involving shore damage caused by vessels under the Extension of Admiralty Jurisdiction Act, 46 U.S.C. $\$ 740(1970)$, as well as the substantive policies in the general maritime law doctrine of maintenance and cure, under which locality is irrelevant for jurisdictional purposes. It is also interesting to notice how this effect of substantive law considerations in some cases allows the plaintiff to assert a cause of action in such a way as to support jurisdiction under one theory where the absence of locality would prevent it under another, e.g., the sustaining of jurisdiction on a complaint amended to include a count sounding in contract after the denial of jurisdiction for want of proper locality in a tort action. Thomson v. Cheasapeake Yacht Club, Inc., 255 F. Supp. 555, 559 (D. Md. 1965).

141. The breadth of the jurisdictional grant is illustrated in note 7 supra, discussing the decisional process whereby the "tidewater limitation" was eventually discarded in favor of the locality test. It is interesting to note that from a very early date acts of Congress purporting to define the extent of admiralty jurisdiction over certain waters have been superseded by judicial decision reinterpreting earlier general maritime jurisdictional grants. See D. ROBERTSON, supra note 7, at 117, which discusses the Supreme Court's decision in The Eagle, 75 U.S. 15 (1868). 
avoiding "absurd" results by insuring that cases brought within the admiralty jurisdiction have a rational connection or relationship with the policies and purposes of maritime law. ${ }^{142}$ For example, if the test requires a determination of locality in any form, either before the maritime nexus determination (or perhaps even in lieu of it) or afterwards as an exclusionary rule in cases where maritime nexus is supportable, it will only serve to produce results that are just as absurd as those the Supreme Court sought to remedy in Executive Jet or else to serve no additional function at all. The only reasonable result dictated by Executive Jet is the interpretation that the locality test has been effectively rejected, ${ }^{143}$ leaving the maritime nexus as the only operative portion of the rule of admiralty jurisdiction. Nevertheless, without additional focus, the maritime nexus test itself would spawn excessive litigation and would threaten to consume an inordinate amount of judicial energy and litigant time in groping for resolutions under an unpredictable jurisdictional test. Therefore, it becomes necessary for commentators and for the courts to attempt to define the characteristics which inhere in the fundamental concept of the "maritime nexus." 144

142. It is just as important to establish as a guiding jurisdictional principle that the admiralty powers of the federal courts should not be employed without assuring that supporting substantive policies will thereby be served, as it is to enumerate all of those substantive policies in all maritime areas. The latter task is beyond the scope of this Article and, moreover, beyond the coverage of most good hornbooks. Thus the examples of substantive policies at stake in the cases discussed should suffice to illustrate the principal advantage of our proposed test: that it adverts one to the substantive policies and developed lines of case law in the maritime area involved in his caso, directly or by analogy, rather than attempting to enumerate an inclusive checklist of all substantive maritime concerns. The employment by analogy of cases dealing with the definition of vessels and involving the maritime policies of regulating this important instrument of maritime commerce can be observed in the Higginbotham case. See text accompanying note 97 supra. Likewise, the case law concerning seamen and tho different but equally important policy of providing uniform regulation over them may be seen as a substantive analogy used to support jurisdiction in other cases. Our point is, of course, that only some cases do this with any precision and hardly any with settled procedural techniques. Thus our proposed rule in settling the functional, procedural focus serves to allow the litigant to employ the easily discoverable substantive background in lis case which will or will not make it "maritime" rather than attempting to catalog all maritime things.

143. The other interpretations, see text accompanying notes $60-65$ supra, all retain a significant role for the locality aspect in the jurisdictional test.

144. Another attempt to resolve the ambiguous jurisdictional rule into a more workable standard may be found in Note, Admiralty Jurisdiction: Executive Jet in Historical Perspective, supra note 7. Those authors do not advert to the diversity of procedural approaches to applying the jurisdictional test employed by the various courts in the Executive Jet litigation. Id. at 366. They do, however, advocate that locality should not be used to preclude admiralty jurisdiction where other "maritime 
To this end we propose the following jurisdictional test, to be used in all tort cases involving general maritime law, that is, where no statute with special jurisdictional provisions is applicable:

That jurisdiction to adjudicate tort cases in admiralty should be asserted (i) in any case imvolving the commission of a tort by a maritime defendant or (ii) in the absence of (i), above, where a tort is committed against a maritime plaintiff.

The maritime character of the defendant in classic situations would be defined by the presence of a commercial maritime vessel or its instrumentalities as the tortfeasor. Where a classic maritime agency is not involved, the post-Executive Jet cases already point to a process of assessing the maritime character of the defendant by a sort of functional analog to classic maritime activities, sucl1 as was the case when a helicopter was performing the functions of a crewboat, ${ }^{145}$ or as in the analogy between ocean voyages and transoceanic fliglits suggested in Executive Jet ${ }^{\mathbf{1 4 6}}$ and followed in Hark v. Antilles Airboats,

nexus" factors are present, and they attempt to articulate the contents of the "maritime nexus" test. Id. at 369 . They include among relevant "maritime nexus" factors (1) locality, (2) state governmental interest, (3) national governmental interest, and (4) the integrity of admiralty law. However, such an approach to solving the problems created by the new jurisdictional rule is insufficient in that it fails to arrive at either a definition based on the functions and interests of the parties or procedural clarity. Further, following the case of Kelly v. Smith, 485 F.2d 520 (5th Cir. 1973), they articulate a number of reasonable policy objectives or ends without providing sufficient procedural definition for the jurisdictional rule. In short, the ends are defined without reference to a definition of the means. We argue that it is essential to have a jurisdictional test which even though designed to serve such objectives, does more than list them. The constaut groping for some rule with formal definitiou which will in most cases serve the numerated policy goals is one of the main characteristics of the post-Executive Jet jurisdictional hitigation and a pervasive symptom of the failure of the new test to meet the standards of a "good" jurisdictional rule.

145. Higgiubotham v. Mobil Oil Corp., 357 F. Supp. 1164 (W.D. La. 1973), discussed in notes 97-98 supra. For a case employing the same approach as Higginbotham, but reaching a different result, see Teachey v. United States, 363 F. Supp. 1197 (M.D. Fla. 1973). There the court denied admiralty jurisdiction in a suit by a plaintiff killed in a Coast Guard helicopter after being rescued by the helicopter from a sinking boat. The court upheld the defendant's motion to dismiss despite plaintiff's argnment that the helicopter was engaged in the ordinary functions of a boat, and thus satisfied the "maritime nexus" test. The court denied jurisdiction because the helicopter crashed after it had completed the rescue operation and while it was in route to another destination after refueling on land. The court stated:

This argument fails, however, in that the complaint alleges specifically that the helicopter crashed, not in the performance of an air sea rescue operation, but rather after the rescue had been effected .... In the view of this Court, the mere transportation of the decedent by aircraft from one Coast Guard base to another does not constitute a sufficient act of performing a function traditionally performed by waterborne vessels so as to bring it within the dictum statement enunciated in Executive Jet . . . I Id. at 1199.

146. 409 U.S. at 271 . 
Inc. ${ }^{147}$ This test permits of flexible and yet definable results.

The test proposed here would initially focus upon the agency causing the harm to insure application of uniform principles of maritime law whenever that agency can be rationally identified as having essentially a maritime function. It would, in addition to providing procedural clarity, be sufficiently broad so as not to exclude inatters from admiralty jurisdiction which should be within it, a result which might be produced by the application of the narrow, rather undefined "plaintiff's exclusionary approach" taken in Onley v. South Carolina Electric $\&$ Gas $C o .{ }^{148}$ or the rule which assumes that the cases are sufficiently clear so that jurisdictional "borderline" cases can be treated under a special "borderline" application of the rule. ${ }^{149}$

Furthermore, the maritime character of a plaintiff, if necessary, would be determined by the same analytic method, requiring either a conventional seaman or some other plaintiff engaged in a function traditionally performed by a maritime agent in order to invoke admiralty jurisdiction This branch of the test is necessary and appropriate to insure that admiralty jurisdiction is not mechanically granted or denied, but in all cases may be invoked only on the basis of a full consideration of the functions performed by all the parties to the action at the time the tort arose. ${ }^{150}$ It should not make any difference whether the maritime party is on the plaintiff's side of the lawsuit instead of that of the defendant, for to make the jurisdiction turn on that distinction alone would simply reward the first to reach the courthouse.

The great majority of all cases will probably be determined under provision (i) in the proposed rule, concerning a maritime defendant. It would rarely be necessary to resort to provision (ii) to resolve a jurisdictional dispute. For example, virtually all of the post-Executive

147. 355 F. Supp. 683 (D.V.I. 1973).

148. See text accompanying notes 113-15 supra.

149. See Maryland v. Amerada Hess Corp., 356 F. Supp. 975 (D. Md. 1973).

150. For an example of a case dealing with injury to a maritime plaintiff as opposed to injury caused by a maritime defendant, see Oppen v. Aetna Ins. Co., 485 F.2d 252 (9th Cir. 1973). This case dealt with suits against the insurer of an oil company by the owner of private pleasure boats whose craft were danaged by oil spills from the company's offshore drilling platform. In upholding admiralty jurisdiction, the court stated:

In our case plaintiffs sought dainages for physical injury to maritime vessels and for interference with their right of navigation. Such claims do bear a significant relationship to traditional maritime activity. It is precisely plaintiffs' alleged rights to engage in "traditional maritime activity" that they are seeking to protect. Id. at 257.

Thus, this case would clearly fit within part (ii) of our proposed test. 
Jet jurisdictional decisions involved a defendant who was allegedly maritime or engaged in traditional maritime activities or their equivalent. Moreover, it would be rare that a plaintiff who would under the proposed test be considered maritime would not be accompanied by a similarly martime defendant. Such an unlikely case might be the effective reverse of the situation in Star of India, where a vessel would sue a passenger or visitor for property damage to the vessel. The first category of the proposed rule would, then, effectively deal with all but the occasional case. Further, possible exceptions could, if necessary, be made in the application of the latter provision of the proposed rule, section (ii), which would not disturb the consistency and efficiency of jurisdictional adjudication precisely because occasions for the use of such exceptions would be rare.

\section{CONCLUSION}

Professor Black in 1950 characterized his critique of the admiralty jurisdictional tests as an attempt "to provoke discussion of the present basic scheme for the allocation of judicial jurisdiction in maritime cases, rather than to present a new plan thought to be defensible from all angles." 151 His general suggestions for change were, in his own words, "an invitation to further definition at lower levels of generality."152 This aim is as important and, unfortunately, as unfulfilled now as it was then. However, the trends and theoretical changes in jurisdictional case law have assumed more definition in the past twenty-five years, and now provide an observable pattern which points the way to probable future developments. Out of this pattern we hope to have provided the sought-after lower level of generality in the area of admiralty tort jurisdiction by pointing to the most plausible and useful jurisdictional approaches employed in the modern case law. If the test we suggest does not in whole or in part emerge in future experiments, we at least hope to have provoked some of the essential discussion and analysis which Professor Black advocated long ago.

151. Black, supra note 1 , at 280.

152. Id. 
, 